\title{
The Frayed and Tarnished Silver Thread: StinchCombe AND The Role of Crown Counsel in Alberta
}

\author{
GLEN E. LUTHER
}

The Supreme Court of Canada has repeatedly stressed that, in their roles as Crown prosecutors. Crown counsel must act as ministers of justice in order to protect against wrongful convictions. Historically this obligation has been referred to as a silver thread woven into "the web of Canadian criminal law."

Central to this quasi-judicial Crown obligation is disclosure. In this article, the author contends that the Supreme Court ideal of Crown prosecutors acting as ministers of justice and making full disclosure does not correspond with reality. Rather, it is asserted that the Crown delegates disclosure duties to the police, does not take disclosure obligations seriously, and is not held responsible by the courts for failure to disclose. The author argues that until the Supreme Court clarifies the required scope of disclosure, especially as regards Charter defences; until Crown prosecution offices are prepared and equipped to take the disclosure role seriously; and until the courts enforce this role; there will continue to be wrongful convictions due 10 lack of disclosure.
La Cour suprème du Canada a maintes fois souligné qu'en tant que procureurs de la Couronne, les procureurs doivent agir en ministre de la justice afin d'èviter les condamnations injustifiées. Traditionnellement, cette obligation a été considérée comme un fll d'argent " tissé dans létoffe du droit criminel canadien ".

Au caur de cette obligation quasi-judiciaire de la Couronne se trouve la question de la divulgation. Dans cet article, l'auteur soutient que pour la Cour suprême du Canada, le procureur idéal agissant en ministre de la justice et communiquant pleinement la prewve ne correspond pas à la réalité. On fait plutôt valoir le fait que la Couronne délègue cette responsabilite à la police, qu'elle ne prend pas cette obligation au sérieux et que les tribunaux ne tiennent pas la Couronne responsable en cas de défaut de divulguer. L'auteur estime que tant que la Cour suprême n'a pas clarifié la portée requise de la divulgation, surtout en ce qui concerne les défenses en vertu de la Charte, que les bureaux des procureurs ne sont pas préparés ni prêts à prendre la divulgation au sérieux et que les tribunaux ne sont pas prèts à appliquer ce rôle, il y aura des condamnations injustifiées causées par un manque de divulgation.

\section{TABLE OF CONTENTS}

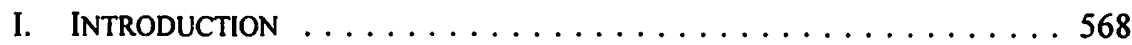

II. The SuPreme Court Polishes the Silver THREAD $\ldots \ldots \ldots 568$

III. STRETCHING THE Silver THREAD TO THE LiMiT:

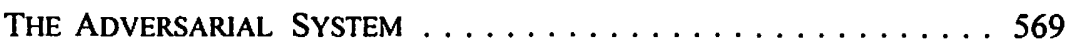

IV. REWINDING THE SILVER THREAD:

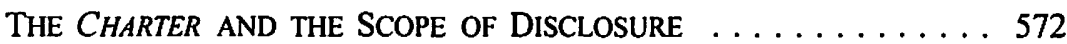

V. "THE DEFENCE IS Always AT FAulT": THE SILVER

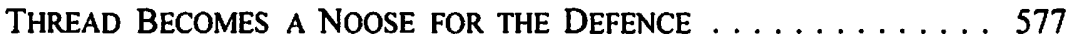

VI. HIDING THE SILVER THREAD: THE POlice DID IT $\ldots \ldots \ldots \ldots 581$

VII. THE FRAYING OF THE SILVER THREAD:

DEDICATION, WORKLOAD AND EXPERIENCE $\ldots \ldots \ldots \ldots \ldots 584$

LL.B. (Saskatchewan), LL.M. (Queen's). The author is a member of the Alberta and Saskatchewan Bars and most recently was also a member of the Law Faculty at the University of Calgary from 1999-2002. He is a member of the law firm Scott Hall in Calgary and will join the College of Law at the University of Saskatchewan in 2003. The writer would like to acknowledge the funding of the University of Calgary Grant Program for assisting with the research that went into this article. Thanks also to James Pickard for his valuable research assistance. 
VIII. STRENGTHENING THE SILVER THREAD:

A HATCHET NOT A SCALPEL $\ldots \ldots \ldots \ldots \ldots \ldots \ldots \ldots 7$

IX

CONCLUSION .......................... 592

\section{INTRODUCTION}

If throughout the web of Canadian criminal law one golden thread is always to be seen, namely, that it is the duty of the prosecution to prove the prisoner's guilt, then equally it may be said that a silver thread is also always to be seen, namely, that Crown counsel regards himself as a part of the Court. and acts in a quasi-judicial capacity to assist toward the due administration of criminal law and justice, in contrast to the attitude of prosecuting counsel in some other countries.'

So said Justice McBride of the Appellate Division of the Supreme Court of Alberta, as it then was, in $R$. v. Pearson in 1957. As the silver thread, prosecuting counsel act as "ministers of justice" in a quasi-judicial capacity with no thought of winning or losing. This role has been stressed repeatedly by the Supreme Court of Canada from Boucher v. The Queen ${ }^{2}$ in 1954, in R. v. Stinchcombe in 1991, Proulx v. Quebec (A.G.) in 2001, and most recently in $R$. v. Regan ${ }^{5}$ and $R$. v. Brown ${ }^{6}$ in 2002.

\section{The Supreme Court Polishes the Silver Thread}

In Brown, Major J., for a unanimous Court, stated:

The Crown must act in the public interest in determining whether to proceed to trial and whether there is sufficient evidence to secure a conviction. The Crown has a public duty to avoid the irrongful conviction of accused individuals. ${ }^{7}$

The duty of the Crown to avoid wrongful convictions played a central role in the Court's judgment in Proulx. There the Court upheld a suit for malicious prosecution and, in commenting on what standard is applicable to prosecutors in deciding whether to initiate or continue a prosecution, the majority said,

However, in our opinion, the Crown must have sufficient evidence to believe that guilt could properly be proved beyond a reasonable doubt before reasonable and probable cause exists, and criminal proceedings can be initiated. A lower threshold for initiating prosecutions would be incompatible with the Prosecutor's role as a public officer charged with ensuring justice is respected and pursued. ${ }^{8}$

The use of the word "properly" in the above passage seems a deliberate choice by the Court, especially when emphasised again by the majority shortly thereafter:

R. v. Pearson (1957), 117 C.C.C. 249 at 260 [emphasis added].

[1955] S.C.R. 16 [hereinafter Boucher].

[1991] 3 S.C.R. 326 [hereinafter Stinchcombe].

[2001] S.C.J. No. 65, online: QL (SCJ) [hereinafter Proulx].

[2002] S.C.J. No. 14, online: QL (SCJ) [hereinafter Regan].

[2002] S.C.J. No. 35, online: QL (SCJ) [hereinafter Brown].

lbid. at para. 79 [emphasis added].

Proulx, supra note 4 at para. 31 [emphasis in original]. 
We think it must have been clear to the Prosecutor on March 20,1991, when he authorized the charge of first degree murder against the appellant, that this evidence could not properly have resulted in a conviction. ${ }^{9}$

Indeed, the silver thread was central to the ruling in Stinchcombe relating to disclosure, particularly in relation to the assessment of relevance. The unanimous Court in Stinchcombe held that

The experience to be gained from the civil side of the practice is that counsel, as officers of the court and acting responsibly, can be relied upon not to withhold pertinent information. Transgressions with respect to this duty constitute a very serious breach of legal ethics. ${ }^{10}$

\section{STRETCHING THE SILVER THREAD TO THE LIMIT: THE ADVERSARIAL SYSTEM}

The Supreme Court has clearly stressed the role of the Crown prosecutor as a quasijudicial officer to protect against wrongful convictions. The role of disclosure is central to that protection. In this article I suggest that the view of Crown counsel as minister of justice making full disclosure does not accord with my observations of the actual practice of disclosure - if not the practice of criminal law generally. If my experience is representative of a broader trend, the picture presented is deeply disconcerting. Stinchcombe itself is confusing and unclear on the scope of disclosure, resulting in a lack of trust between Crown counsel and defence lawyers, and leading to lengthy "disclosure hearings." The Crown has often delegated the review of files for disclosure to the police, and often acts as a simple conduit in the provision of disclosure. The Crown does not take seriously its disclosure obligations and is hampered by a lack of support from government. The courts have, in turn, failed to hold either the police or the Crown responsible for failings in the provision of disclosure to the defence. Until Crown prosecution offices are prepared and equipped (perhaps forced by the courts to become so equipped) to take this role seriously, we will continue to face wrongful convictions due to lack of disclosure.

The Boucher view of Crown counsel, the silver thread, is one that has impressive credentials and has been stressed repeatedly. Since Stinchcombe the Supreme Court has suggested that some aspects of the Crown's traditional duties have been diluted as a result of the decision. In $R$. v. Cook, the Supreme Court held that while it may be tactically unwise for the Crown not to call a complainant as a witness at trial, the Crown is not obligated to do so. In part, the Court justified its decision on Stinchcombe principles. Justice L'Heureux-Dubé said:

In my view, any rationale compelling the Crown to call witnesses based on the need 10 bring all material facts forward was extinguished by developments in the law of disclosure. It is simply no 
longer correct to suggest that the defence will ever be "ambushed" by the Crown's failure to call a material witness."

Speaking for the Court in Cook, L'Heureux-Dubé J. acknowledged the conflict inherent in the prosecution's public duty and the adversarial system. ${ }^{12}$ Although the Crown "cannot adopt a purely adversarial role toward the defence" given its "special function in ensuring that justice is served," it is "permissible and desirable that [the Crown] vigorously pursue a legitimate result to the best of its ability."' Lawyers, of course, think of the criminal justice system as an adversarial system. The import of this is that two sides battle in a contest. The truth is that the system is actually less of an adversarial system than this simplistic view allows when one considers the "quasjjudicial role of the Crown" with the burden of proof being on the Crown to prove (the inherently unbalanced) guilt beyond a reasonable doubt.

\title{
Justice L'Heureux-Dubé says,
}

\begin{abstract}
Nevertheless, while it is without question that the Crown performs a special function in ensuring that justice is served and cannot adopt a purely adversarial role towards the defence it is well recognized that the adversarial process is an important part of our judicial system and an accepted tool in our search for the truth. Nor should it be assumed that the Crown cannot act as a strong advocate within this adversarial process. In that regard, it is both permissible and desirable that it vigorously pursue a legitimate result to the best of its ability. Indeed, this is a critical element of this country's criminal law mechanism. ${ }^{14}$
\end{abstract}

The Crown prosecutor is, according to this view, a "minister of justice" in its "administrative tasks" and an adversary in its "trial conduct tasks."' This view was supported by Lord Devlin, who asserted in 1956 that prosecutors in England had become "frightened of being accused of an excess of fervour" as the pendulum had swung too far towards the quasi-judicial role, placing the burden upon the presiding judge and upsetting the balance of the trial. ${ }^{16}$ Likewise, Zuber J.A. stated in $R$. v. Savion and Mizrahi that "a Crown prosecutor is an advocate; he is entitled to discharge his duties with industry, skill and vigour."

This assessment of the Crown's role is overly simplistic. The duty to disclose, for example, involves ongoing obligations that may well arise in the trial and, at this point,

R. v. Cook, [1997] 1 S.C.R. 1113 at para. 36 [emphasis added] [hereinafter Cook]. It is submitted that the "ambush" ignored by the Court is not the fact of the content of the witness's evidence, but the failure to call the witness, perhaps without notice.

See the article by Gavin MacKenzie - who once held the position of senior discipline officer for the Law Society of Upper Canada - called "Breaking the Dichotomy Habit: The Adversary System and the Ethics of Professionalism" (1996) 9 Can. J.L. \& Jur. 33. Cook, supra note 11 at para. 21.

Ibid. [citations omitted] [emphasis added]. Disclosure. and Resolution Discussions (Toronto: Ministry of the Attomey General, 1993) at 31-34 [hereinafter Martin Report]. 
the prosecutor's duty to disclose new information remains. ${ }^{18}$ Further, if the Crown has a duty to protect from wrongful convictions, that duty cannot stop at the courthouse steps. For instance, Courts of Appeal have struggled to control the Crown's conduct at trials particularly when dealing with allegations of over-vigorous cross-examinations of accuseds. The Alberta Court of Appeal in $R$. v. Kusk stated,

The second reason not to apply the proviso is that many appellate courts have condemned such crossexamination, especially by prosecutors questioning the accused, since at least 1925. We are not aware of any modern authority allowing it. Yet it keeps happening, as the number of modern decided cases shows. In one province (not Alberta), there are so many appellate decisions condemning the practice, but not ordering a new trial, that one wonders whether the prosecutors there think that it is a matter of "Do as I say, not as / do". Maybe that is why they keep asking the forbidden question. The practice should stop at once, and there is an obvious way to stop it. ${ }^{19}$

Further, the law of evidence is replete with special rules protecting the accused that are of long standing and that are different from those that apply to other witnesses. ${ }^{20}$

The criminal trial, properly understood, is not a true adversarial battle. The role played by the parties is unbalanced. The above cases show a dedication on the part of the Supreme Court to the silver thread role of the prosecutor, on the one hand, with defence counsel striving to win at almost any cost, on the other. The mismatch presented reminds one of a game of tennis where one player is an accomplished master and the other a beginner. The veteran does not strive to win. Indeed, she tries to make the game fair. ${ }^{21}$ The roles of defence counsel and the Crown should be seen as having the same aim: to ensure no one is wrongfully convicted. The focus needs to remain so.

It is a serious dilemma that in Stinchcombe the Supreme Court laid the obligation of ensuring disclosure at the feet of Crown counsel. It is submitted that the view that they can be trusted to disclose needs support from at least three quarters. First, the Supreme

Stinchcombe, supra note 3 at para. 28, where the Court said: "the obligation to disclose is a continuing one and disclosure must be completed when additional information is received." R. v. Kusk (1999), 132 C.C.C. (3d) 559 at para. 9 [emphasis added]. The reference to another province is presumably Ontario. See, e.g., $R$. v. Robinson (2001), 153 C.C.C. (3d) 398 (Ont. C.A.) where that Court did order a new trial, saying at para. 35 :

In my view, Crown counsel's cross-examination of the appellant was highly improper. From start to finish, it was designed to demean and denigrate the appellant and portray him as a fraudsman, a freeloader and a demented sexual pervert. Many of the questions posed were laced with sarcasm and framed in a manner that made it apparent that Crown counsel personally held the appellant in utter contempt. In many respects, this was not a crossexamination but an attempt at character assassination.

See also $R$. v. Henderson (1999), 134 C.C.C. (3d) 131 (Ont. C.A.); R. v. S.(F.) (2000), 144 C.C.C. (3d) 466 (Ont. C.A.) and $R$. v. A.J.R. (1994), 94 C.C.C. (3d) 168 (Ont. C.A.).

See, e.g., the special rules relating to character evidence in $R$. v. Davison, DeRosie and MacArthur (1974), 20 C.C.C. (2d) 424 (Ont. C.A.) and Corbett v. The Queen (1988), 41 C.C.C. (3d) 385 (S.C.C.). See also Titus v. The Queen (1983), 2 C.C.C. (3d) 321 (S.C.C.) [hereinafter Titus] and Koufis v. The King (1941), 76 C.C.C. 161 (S.C.C.) [hereinafter Koufis].

21 Such comparisons are dangerous. I do not suggest that the Crown needs to do defence counsel's job. Clearly, in striving to remain fair, the Crown maintains the obligation to the public to attempt to ensure guilty people are convicted, but only where that can be done fairly. 
Court needs to face the question as to the scope of disclosure and make clear that it includes all information, including that relating to Charter ${ }^{22}$ defences. Second, Crown counsel need to be given the staffing numbers, resources, and commensurate benefits equal to the difficult job the courts have assigned them. Third, procedures and remedies must be in place that will effectively force serious attention on the issue of that disclosure obligation.

\section{REWINDING THE SILVER THREAD: THE CHARTER AND THE SCOPE OF DISClOSURE}

The Charter holds a difficult position in criminal law. In many ways it has complicated the law, to the dismay of those on the Crown's side of the courtroom. From the rookie police officer to the experienced prosecutor, the Charter has been perceived as placing a major stumbling-block on the path to successful investigations and prosecutions. This can and does create a sense of disillusionment that can be counterproductive to fair prosecutions. This is no less true for the obligation to disclose. Prosecutors complain daily that they should not be required to go on fishing expeditions for the defence. In $R$. v. Chaplin, the Supreme Court gave considerable relief to the Crown when the Court said,

in some cases, this being one, the existence of material which is alleged to be relevant is disputed by the Crown. Once the Crown alleges that it has fulfilled its obligation to produce it cannot be required to justify the non-disclosure of material the existence of which it is unaware or denies. Before anything further is required of the Crown, therefore, the defence must establish a basis which could enable the presiding judge to conclude that there is in existence further material which is potentially relevant. Relevance means that there is a reasonable possibility of being useful to the accused in making full answer and defence. The existence of the disputed material must be sufficiently identified not only to reveal its nature but also to enable the presiding judge to determine that it may meet the test with respect to material which the Crown is obliged to produce. ${ }^{23}$

The Court justified its decision on the basis that "[f]ishing expeditions and conjecture must be separated from legitimate requests for disclosure." ${ }^{24}$ The Court apparently felt that the defence had to take the Crown's word when it assured the defence and the court that full disclosure had been made. This, of course, is not what Stinchcombe held. There the Court had said the Crown's discretion not to disclose in a case of disputed relevance was reviewable by the trial judge on application by the defence. On the application, the onus was on the Crown to justify the non-disclosure. ${ }^{25}$ The problem in Chaplin, though, was that the Crown refused to say whether certain material was even in existence, let alone relevant.

Canadian Charter of Rights and Freedoms, s. 7, Part 1 of the Constitution Act, 1982, being Schedule B to the Canada Act 1982 (U.K.), 1982, c. 11 [hereinafter Charter]. 
The problem presented highlights the confusion in the Stinchcombe decision between relevance and materiality. In Stinchcombe Sopinka J. held:

With respect to what should be disclosed, the general principle to which I have referred is that all relevant information must be disclosed subject to the reviewable discretion of the Crown. The material must include not only that which the Crown intends to introduce into evidence but also that which it does not. No distinction should be made between inculpatory and exculpatory evidence. The attempt to make this distinction in connection with the confession rule proved to be unworkable and was eventually discarded by this Court. To re-introduce the distinction here would lead to interminable controversy at trial that should be avoided. The Crown must, therefore, disclose relevant material whether it is inculpatory or exculpatory. ${ }^{26}$

Unfortunately, we have recently seen such "interminable" controversies arise; "disclosure hearings" have become commonplace and very lengthy, especially in major investigations. ${ }^{27}$ The Crown often seems to feel that it is not required to disclose matters not in the police investigational file. The example of the bankruptcy file in Stinchcombe shows this reasoning to be false. ${ }^{28}$

Further, the Crown often sees matters that relate to due process issues (arising out of Charter rights) as not relevant, at least until the defence raises those rights in the case. It is not uncommon to hear reference by Crown counsel to the "shifting sands of relevance." In a wiretap case, for example, is the legality of the authorization relevant at the outset, or does it become relevant only once the defence has filed notice that the legality and constitutionality of the order is an issue in the case? Stinchcombe has created this confusion by focusing on "relevance" to the exclusion of materiality. While it is clear that the touchstone of relevance is not admissibility but rather usefulness in preparing a defence, the Court does not assist by ignoring "materiality" which has often resulted in the Crown not disclosing information that might be said to go only to the breach of a Charter right and not innocence in fact.

\section{Stinchcombe does say that}

A discretion must also be exercised with respect to the relevance of information. While the Crown must err on the side of inclusion, it need not produce what is clearly irrelevant. The experience to be gained from the civil side of the practice is that counsel, as officers of the court and acting responsibly, can be relied upon not to withhold pertinent information. Transgressions with respect to this duty constitute a very serious breach of legal ethics. The initial obligation to separate "the wheat from the chaff" must therefore rest with Crown counsel. ${ }^{29}$

By speaking of relevance only, the question remains: relevant to what? I suggest that relevance is a meaningful concept only if one knows to which issues one must direct

Ibid. at para. 29 [citations omitted] [emphasis added].

See, e.g., the recent judgment of Binder J. in R. v. Trang, [2002] A.J. No. 1008 (Q.B.), online: QL (AJ).

See the article by John K. Phillips in this issue at 539.

Stinchcombe, supra note 3 at para. 20. 
one's attention in making disclosure decisions. As stated by Professors Paciocco and Stuesser in the context of admissibility, "Information can be admitted as evidence where it is relevant to a material issue in the case." ${ }^{30}$ For the Crown to be able to make a relevance determination, it is essential for the Crown to know what are the issues in the case. In the context of disclosure this obviously means what are the possible issues in the case. ${ }^{31}$ In $R$. v. Egger, the Supreme Court said,

The trial judge reviewing the Crown's disclosure decisions, and by backward extension the Crown itself in exercising its discretion,

should be guided by the general principle that information ought not to be withheld if there is a reasonable possibility that the withholding of information will impair the right of the accused to make full answer and defence, unless the non-disclosure is justified by the law of privilege.

One measure of the relevance of information in the Crown's hands is its usefulness to the defence: if it is of some use, it is relevant and should be disclosed.... This requires a determination by the reviewing judge that production of the information can reasonably be used by the accused either in meeting the case for the Crown, advancing a defence or otherwise in making a decision which may affect the conduct of the defence such as, for example, whether to call evidence. ${ }^{32}$

As Charter rights can result in findings of "not guilty," due to the exclusion of evidence, such issues are material to any prosecution and they are therefore material issues to be taken into account by Crown counsel when making disclosure decisions.

A similar controversy has arisen in the context of solicitor-client privilege issues where the exception to solicitor-client privilege has been described by the Supreme Court as the "innocence-at-stake" exception. ${ }^{33}$ The issue has arisen whether the exception is engaged where, although not going to innocence in fact, the information may be relevant to abuse of process issues. ${ }^{34}$ I suggest that the Supreme Court has, in expressing the exception in terms of "innocence," confused the burdens of proof in criminal litigation. If "innocence" means innocence in fact, then it wrongly places the focus on whether the accused committed the offence rather than on whether the offence can be proved. The verdict of "not guilty" reflects the relevant issue in criminal litigation. The presumption of innocence presumably requires the assumption that the accused did not commit the offence and therefore innocence is always "at stake" until such time as the Crown can prove otherwise.

D. Paciocco \& L. Stuesser, The Law of Evidence, 2d ed. (Toronto: Irwin Law, 1999) at 17. R. v. Dixon (1998), 122 C.C.C. (3d) I at para. 34 (S.C.C.) [hereinafter Dixon]. [1993] 2 S.C.R. 451 at para. 20 [citations omitted] [emphasis added]. See R. v. Campbell, [1999] I S.C.R. 565 [hereinafter Campbell]; R. v. McClure (2001), 151 C.C.C. (3d) 321 (S.C.C.) [hereinafter McClure] and Brown, supra note 6.

Here I use the phrase "innocence in fact" to mean an accused who has either not committed the actus reus with the necessary mens rea or, if the accused has done so, where the accused is able to rely on a "common law" (i.e., non-Charter) defence. 
The British Columbia Court of Appeal has held that innocence-at-stake includes abuse of process. In $R$. v. Creswell Ryan J.A. held as follows:

In my view, these cases support the notion that innocence at stake includes defending a charge on the basis that the unfair treatment of the accused disentitles the Crown to carry on with the prosecution of the charge or charges. Although the accused is the moving party and bears the onus of proving that a stay ought to be granted, the application for the stay, is nevertheless, in the words of Caulfield $J$. in $R$ v. Barton, supra, an "answer to an allegation made by the Crown". It therefore clearly falls within the innocence at stake exception. ${ }^{35}$

Further in $R$. v. Scott, where Cory J. for the majority, in discussing the innocence-atstake exception to "informer privilege," said,

A third exception may exist where the accused seeks to establish that the search was not undertaken on reasonable grounds and therefore contravened the provisions of $s .8$ of the Charter. Even under these conditions, a court should strive to provide as much evidence as possible to the defence by means of editing the information on which the search warrant was based without disclosing the identity of the informer. That disclosure should only be made in circumstances where it is absolutely essential. ${ }^{36}$

If the innocence-at-stake exception includes Charter breaches committed during the investigation and prosecution then so too must possible relevance include Charter issues. Such information is certainly useful to the defence in defending the charge in question. The defence, without disclosure, is in a Catch-22 situation without knowledge of the document's existence, let alone its content. ${ }^{37}$ This can only lead to voluminous and lengthy demands for disclosure and disclosure hearings if disclosure does not include such information in the first instance.

One might also consider the meaning of the phrase "wrongful conviction." It is now clear to everyone involved in the administration of criminal justice that the conviction of an innocent person is a tragedy our society cannot countenance. As cited by the

(2000), 149 C.C.C. (3d) 286 at para. 51 [hereinafter Creswell], citing R. v. Barton, [1972] 2 All E.R. I192, where Caulfield J. had ruled at I194,

If there are documents in the possession or control of a solicitor which, on production, help to further the defence of an accused man, then in my judgment no privilege attaches. 1 cannot conceive that our law would permit a solicitor or other person to screen from a jury information which, if disclosed to the jury, would perhaps enable a man either to establish his innocence or to resist an allegation made by the Crown. I think that is the principle that should be followed.

See also $R$. v. Desabrais (2000), 149 C.C.C. (3d) 305. The Court of Appeal recently held that Creswell remains good law after the Supreme Court's decision in McClure, supra note 33, in $R$. v. Castro (2001), 157 C.C.C. (3d) 255 at para. 38, leave to appeal to S.C.C. refused [2001] S.C.C.A. No. 533, online: QL (CJ). For a useful discussion of Charter disclosure see C. Sherrin \& P. Downes, The Criminal Lawyers' Guide to Disclosure and Production (Aurora: Canada Law Book, 2000) at 30. 
well-known Martin Report, ${ }^{38}$ Lord Morris said in S. (An Infant) v. Recorder of Manchester,

The desire of any Court must be to ensure, so far as possible, that only those are punished who are in fact guilty. The duty of a Court to clear the innocent must be equal or superior in importance to its duty to convict and punish the guilty. ${ }^{39}$

However, the Court in Stinchcombe saw the need for full disclosure to go beyond protecting the innocent and to include due process considerations. In Stinchcombe, Sopinka J. said,

In the Royal Commission on the Donald Marshall, Jr., Prosecution, Vol. 1: Findings and Recommendations (1989), the Commissioners found that prior inconsistent statements were not disclosed to the defence. This was an important contributing factor in the miscarriage of justice which occurred and led the Commission to state that "anything less than complete disclosure by the Crown falls short of decency and fair play. ${ }^{40}$

\section{The Martin Report said,}

The importance to the administration of justice of complete disclosure can scarcely be overstated. First, full disclosure is essential to ensure the fair trial of an accused and to enable him or her to make full answer and defence, which rights are constitutionally protected. Secondly, full disclosure has a beneficial influence on the administration of justice as a whole. Complete disclosure may lead to shorter trials and waived or shorter preliminary inquiries, it may prevent the unnecessary attendance of witnesses, and may facilitate resolution discussions. the withdrawal of charges. and where appropriate, pleas of guilty. ${ }^{41}$

It is central to a fair trial that full disclosure be provided. Anything short thereof can only lead to dissatisfaction with the eventual outcome of the trial and thus to a second category of wrongful conviction.

The difficulty faced by the defence after the decision in Chaplin is that it is told to accept the Crown's assurance that full disclosure has been made. This is so even though the defence cannot know that the Crown has actually taken into account Charter defences in making that assurance. This is, of course, due to the unsettled nature of the law post-Stinchcombe, and has resulted in a lack of trust in Crown counsel. If the Crown routinely disclosed such information, these disputes would arise much less often. While unexpected defences may arise, the Crown must include in disclosure packages any information that relates to any possible defence, including Charter defences. Only

$3 \mathbf{8}$

3)

411

Supra note 15.

[1970] 2 W.L.R. 21 at 37.

Supra note 3 at para. 17, citing the Marshall Report, infra note 44, vol. I at 238 [citations omitted] [emphasis added]. See also the well-known cases of David Milgaard (Reference re Milgaard (Can.), [1992] I S.C.R. 866), G.P. Morin (Ontario, Report of the Commission on Proceedings Involving Guy Paul Morin (Toronto: Ministry of the Attorney General, 1998)), and T. Sophonow (Manitoba, The Inquiry Regarding Thomas Sophonow (Winnipeg: Manitoba Justice, 2001)).

Supra note 15 at 143 [emphasis added]. 
those defences that are not foreseeable by the Crown, after a diligent review, should be the necessary subject of a specific defence demand.

If a prosecutor finds herself asking the question, "Do I have to disclose this document?" one might say that, aside from privilege questions, the answer should always be, "Yes." Asking oneself a question relating to relevance tells one that it is possibly relevant. It is for the defence to decide the use to be made of the document.

\title{
V. "The DEFence is AlWays at FaulT": The Silver Thread Becomes a NoOSe for the Defence
}

On the other hand, one of the oddities of criminal practice is a pervading view that delays in cases are somehow the defence's responsibility due to the commonly held (and sometimes reasonably held) belief that it is in the defence's interest - and therefore a defence tactic - to delay prosecutions. It is not uncommon to hear lawyers, and indeed judges, muse that disclosure issues have bogged down a case due to the defence "insistence" on full disclosure. This is not the responsibility of the defence. Stinchcombe made it clear that

\begin{abstract}
Counsel for the accused must bring to the trial judge's attention at the earliest opportunity any failure of the Crown to comply with its duty to disclose of which counsel becomes aware. This will enable the trial judge to remedy any prejudice to the accused if possible and thus avoid a new trial. ${ }^{42}$
\end{abstract}

The failure of defence counsel to do so has resulted in convictions despite the acknowledged lack of full disclosure ${ }^{43}$ Such rulings perpetuate the myth that defence counsel are somehow at fault for the Crown's unwillingness to make full disclosure.

Indeed, many defence counsel have decided that as a result of the confusion on these issues, their demand for disclosure should include a detailed and very extensive list of material issues. Of necessity these "shopping list" demands are speculative "wish lists" of everything the lawyer thinks might be in existence in relation to a particular case. As such, the lawyer's experience in the kind of case in question will necessarily be important in discovering information in the possession of the Crown. Such a requirement for specific demands for specific information necessarily results in unfairness to accuseds represented by less experienced counsel or perhaps by no lawyer at all. What is required is a due diligence search by Crown counsel of all files for relevant information as defined by Stinchcombe, to allow the Crown, whose obligation it is to provide full disclosure, to certify to the court that full disclosure has been made. Otherwise, the defence has no option but to make voluminous demands and constant applications to the court for further and better disclosure. Many Crown offices have started a process whereby disclosure is made to the accused at first appearance without demand, not necessarily because they see it as their legal obligation to do so but rather as it is more efficient to do so. The lack of trust on these issues has resulted from the

4. See, e.g.. R. v. Biscette (1995), 99 C.C.C. (3d) 326 (Alta. C.A.), aff d (1996), 110 C.C.C. (3d) 285 (S.C.C.). 
failure of the court to insist that the Crown take seriously its obligation to make full and meaningful disclosure in the first instance.

In Stinchcombe the Court was guided at least partially by the report of the Marshall Inquiry which recommended, as quoted by Sopinka J.,

2(1) Without request, the accused is entitled, before being called upon to elect the mode of trial or to plead to the charge of an indictable offence, whichever comes first, and thereafter:

(a) to receive a copy of his criminal record;

(b) to receive a copy of any statement made by him to a person in authority and recorded in writing or to inspect such a statement if it has been recorded by electronic means; and to be informed of the nature and content of any verbal statement alleged to have been made by the accused to a person in authority and to be supplied with any memoranda in existence pertaining thereto;

(c) to inspect anything that the prosecutor proposes to introduce as an exhibit and, where practicable, receive copies thereof;

(d) to receive a copy of any statement made by a person whom the prosecutor proposes to call as a witness or anyone who may be called as a witness, and recorded in writing or, in the absence of a statement, a written summary of the anticipated testimony of the proposed witness, or anyone who may be called as a witness;

(e) to receive any other material or information known to the Crown and which tends to mitigate or negate the defendant's guilt as to the offence charged, or which would tend to reduce his punishment therefor, notwithstanding that the Crown does not intend to introduce such material or information as evidence;

( $f$ to inspect the electronic recording of any statement made by a person whom the prosecutor proposes to call as a witness;

(g) to receive a copy of the criminal record of any proposed witness; and

(h) to receive, where not protected from disclosure by the law, the name and address of any other person who may have information useful to the accused, or other details enabling that person to be identified.

2(2) The disclosure contemplated in subsection (1), paragraphs (d), (e) and (h) shall be provided by the Crown and may be limited only where, upon an inter partes application by the prosecutor, supported by evidence showing a likelihood that such disclosure will endanger the life or safety of such person or interfere with the administration of justice, a justice having jurisdiction in the matter deems it just and proper. ${ }^{44}$

It is interesting to note the phrase "without request" and the later statement that "upon an inter partes application by the prosecutor," both of which the Court did not adopt. The Court erred in not doing so. The obligation the Court placed upon the Crown should have resulted in a requirement of automatic disclosure and, secondly, should have put the onus on the Crown to bring to the Court's attention when they have been unable or unwilling to do so. 
The Court opted for a model that is dependent on three key factors:

(1) Disclosure of all not clearly irrelevant information touching upon the issues;

(2) Defence requests for all not clearly irrelevant information touching upon the issues; and

(3) Defence policing of failure to respond to requests.

This is in direct contrast to the Marshall Report.

In the United States, Federal Rule 16 is the main federal rule governing disclosure of prosecutions covered by those rules. Note that disclosure is governed by a categorial approach. The rule requires that disclosure be provided of information falling within the following categories on demand:

(a) statements of defendant

(b) defendant's prior record

(c) documents and tangible objects

(d) reports of examinations and tests

(e) expert witnesses

While these categories will often mirror what the Stinchcombe rule requires in Canada, it is clear that in the rule the prosecution has no obligation to disclose anything not within these categories. The American rule is therefore much more circumscribed than that suggested by Stinchcombe. On the other hand, the American rule requires that the prosecuting attorney, if she does not accede to a request for disclosure, will make application to be exempted from the requirement to disclose. While leaving the option open to the defence to make an application to require disclosure, it is clear that the initial obligation is on the prosecution to make an application for relief from the disclosure requirement which may result in an order that discovery be "denied, restricted, or deferred, or make such other order as is appropriate." Placing the onus on the prosecution for this purpose makes eminent sense as the onus is placed squarely on the prosecution to disclose all relevant information and only the prosecution can know whether they have done so.

Further, it is of fundamental importance that most Crown offices - in Alberta at least - do not purport to conduct any due diligence search of their files to ensure full disclosure. The bureaucracy of disclosure has seemingly resulted in a practice where, in a standard case, a police officer provides to the Crown the contents of the investigative file. The file itself tends to be created according to a categorical approach as prompted by the police computer system and then an administrative system prompts someone (often not a lawyer) in the Crown office to make disclosure decisions based on the police file only (with the possible exception of the accused's criminal record) ${ }^{45}$ Until recently, the Calgary Crown Prosecutor's Office initial disclosure letter was a 
preprinted form which contained a list with a set of boxes to be checked-off where relevant. Those boxes included

(a) synopsis of offence

(b) copies of witness statements or officer's notes

(c) accused's criminal record

(d) accused's statement

(e) copy of information(s)

(f) other documentation

At the end of the letter there is added a set of blanks where the disclosing person handwrites the witness statements or officer's notes that are attached. ${ }^{46}$

Most telling, perhaps, is that witnesses' criminal records are not disclosed in Alberta absent a specific demand; therefore in many cases a court application is required. ${ }^{47}$ This is despite the fact that, in Stinchcombe, Sopinka J. specifically held that "Complete disclosure would entail not only the identification of such persons, but the disclosure of any statement they made and in some cases their criminal records." ${ }^{148}$ This statement was made in the context of discussing whether the Crown needed to make full disclosure relating to witnesses it did not intend to call. Of course, the Marshall Report had said that criminal records of all proposed Crown witnesses should be disclosed.

The point is that the Alberta Crown never discloses such information without a specific demand. It is not an exercise in Crown discretion - rather the Crown simply does not look for it and therefore does not disclose it (unless perhaps it is in the initially received police report). Disclosure is, in practice, simply a bureaucratic exercise in reviewing the file provided by the police. Any further search of Crown files for information is resented and seen as conducting an investigation for the defence - a "fishing expedition" - even if that record is directly relevant to a particular witness's credibility. ${ }^{49}$ Credibility may be a central issue in the case and may indeed go to innocence in fact. Chaplin would require the defence to make an application showing that the document, here the witness's record as an example, exists. The defence, absent some accidental and likely pre-existing knowledge of the witness's background, is in no position to make such a showing. This evidence may be crucial to the validity of the Crown's case and clearly is properly the subject of cross-examination by the defence. ${ }^{50}$

This letter was recently changed to not include the preprinted list. The current document is entitled "Pickup of Initial Disclosure" and contains no reference to what is included but rather just an acknowledgement of receipt.

It is true of course, that such a record may not be relevant if the credibility of the witness is not an issue in the case or if the witness has no record.

Stinchcombe, supra note 3 at para. 30.

One wonders whether it is not obvious that people do not fish where there are no fish to be caught. See Titus, supra note 20, where the Supreme Court of Canada stated at 324 [emphasis added],

I think it essential to stress the purpose for which the cross-examination is permitted, namely, in order that the defence may explore to the full all factors which might expose the frailty of the evidence called by the prosecution. That the accused as he stands in the prisoner's box on trial for murder is deemed to be innocent until proven guilty beyond a reasonable doubt is one of the fundamental presumptions inherent in the common law and, 
Therefore the said evidence is of central relevance and needs to be disclosed without demand and certainly without the defence being required to follow the Chaplin procedure.

\section{Hiding the Silver Thread: The Police Did It}

A significant issue is, of course, to what extent the Crown is able to rely on the police to gather the appropriate information and whether it is required to at least review the work done by the investigating officers. In $R$. v. Siemens, the Alberta Court of Appeal asked this question:

The issue which we wish to address in more detail is the scope of the obligation of Crown counsel. Disclosure is a duty of the prosecution, which includes Crown counsel, police and other state investigative agencies. Must Crown counsel personally examine and gain knowledge of all evidence before he or she makes a decision as to relevance and disclosure? Or may Crown counsel rely on information presented to him or her by police officers or other civilian employees who have the duty of distilling information and providing it to Crown counsel? ${ }^{51}$

\section{The Court then held,}

While it is clear that Crown counsel has ultimate responsibility for decisions regarding relevance and disclosure of evidence in the possession of the Crown, that in our view does not include a requirement that Crown counsel personally examine and catalogue every item of evidence, every statement, every document, etc., that has been gathered by the police in the course of investigation, or which may be held by other state agencies, to fulfil his or her duty to the accused and the Court.

We recognize that the imposition of such a duty on Crown counsel would create an impossible situation in many cases, such as the present. It is not only in wiretap cases that the Crown must rely on other agencies to make determinations as to relevance of information and provide the Crown with summaries of information which is gathered in the course of an investigation. Police conduct searches, and decide what evidence is to be seized. They provide descriptions of the physical evidence, not the item of evidence itself. In commercial cases, police officers and other staff inspect large volumes of documents and provide resumes to the Crown. They interview witnesses and provide statements, notes or will say outlines. If the current ruling of the trial judge stands and Crown counsel may only make disclosure decisions based on personal inspection and knowledge of all evidence, the system will grind

as such, the accused is entitled to employ every legitimate means of testing the evidence called by the Crown to negative that presumption, and in my opinion this includes the right to explore all circumstances capable of indicating that any of the prosecution witnesses had a motive for favouring the Crown. In my opinion the outstanding indictment preferred against the witness by the same police department that had laid the present charge against Titus constitutes such a circumstance, and accordingly 1 am of opinion that the leamed trial judge did indeed err in precluding defence counsel from pursuing this line of questioning.

It is clear that cross-examination of witnesses, not the accused, is much broader than crossexamination of the accused. See also Koufis, supra note 21 , and the manner in which it is distinguished in Titus by the Supreme Court. That the Crown does not disclose witnesses' records let alone outstanding indictments against a witness effectively denies the accused the right to crossexamine on this evidence. 
to a halt. All searches, witness interviews and investigations will have to be conducted by Crown lawyers so that they, from their own personal knowledge, can say that all relevant evidence has been disclosed.

We see no need for Crown counsel to personally spend days or weeks listening to lengthy tapes, or inspecting documents and other evidence to fulfil the duty of disclosure. Crown counsel is entitled to rely on information provided to him or her by police officers and other staff members regarding the content of documents, especially those considered to have no relevance to proceedings. While the law regarding disclosure deals with obligations of the Crown and speaks of breaches of ethical duties for failure to disclose relevant materials, nothing which we have found in the authorities requires that the burden of examining and cataloguing evidence be assumed by a Crown lawyer. ${ }^{52}$

It is undoubtedly appropriate to include the police in the disclosure duty as they will often have relevant information to which the Crown does not have access. ${ }^{53}$ It is disappointing that the Court did not see fit to require the Crown to take responsibility for decisions made by the police. If the Crown has "ultimate responsibility for decisions regarding relevance and disclosure of evidence in the possession of the Crown," which clearly includes information possessed by the police, then the Crown must be responsible for decisions made for the Crown by the police. The Crown either has responsibility or it does not, and it is hard to see how it has responsibility after this judgment. The judgment in Siemens, in essence, makes the Crown a mere conduit of the disclosure from the police to the accused, and thus flies in the face of the Crown's strong ethical duty to ensure full disclosure is made.

Justice Sopinka suggested in Stinchcombe that the workload of Crown counsel will in fact be decreased by "full disclosure" due to early withdrawals, guilty pleas, waiver of preliminary inquiries and agreements on factual issues. The Siemens Court feels that this has not occurred. One of the problems is institutional: while clearly the Supreme Court saw the new regime as resulting in an overall reduction in trials, it has not meant that every prosecution will be shortened. Rather, it is clear that many cases are greatly extended as a result of disclosure of information that can and does raise issues that otherwise would not have arisen. This is not to be regretted but seen as necessary to fair trial processes and to the accused being able to make full answer and defence.

Given Siemens, it is unclear how the failure of the police to properly assess relevance will be remedied in a particular case. It is central to Stinchcombe that the Crown prosecutor herself, bound by the rules of ethics, make disclosure decisions. ${ }^{54}$ The

s2 Ibid. at paras. 30-32.

33. See also the Martin Report, supra note 15 at 150-53, where the Committee stressed the importance of proper police note-taking.

st See also Chaplin, supra note 23, where the Court said at para. 21 [emphasis added], This Court has clearly established that the Crown is under a general duty to disclose all information, whether inculpatory or exculpatory, except evidence that is beyond the control of the prosecution, clearly irrelevant, or privileged: $R$. v. Stinchcombe, supra, at p. 339; $R$. v. Egger, [1993] 2 S.C.R. 451. The Crown obligation to disclose all relevant and nonprivileged evidence, whether favourable or unfavourable, to the accused requires that the Crown exercise the utmost good faith in determining which information must be disclosed 
corollary is the critical need for serious and effective remedies for police failures to follow the dictates of the law. Further, it is ironic that while Justice Canada suggests that it is essential for the police to co-operate with the Crown due to the complexity of the law, ${ }^{55}$ the Crown is essentially hiding behind the police and thereby ducking responsibility for disclosure mistakes. This is especially problematic when the discussions between the police and the Crown are asserted to be protected and privileged as solicitor-client communications and therefore not disclosable. ${ }^{56}$

This is further complicated by the fact that some lower courts have gone so far as to hold that relevant information held by the police on separate investigations, not relating to the accused before the court, are not possessed by the Crown and therefore not disclosable under Stinchcombe. ${ }^{57}$ These rulings, holding that in such situations the more onerous $O^{\prime} \mathrm{Connor}^{58}$ procedure must be followed, drive an unwarranted and unjust stake through Stinchcombe. If the information from the other police file is relevant, whether or not the accused was the target of that investigation, it must be disclosed. While it may be different if one is speaking of non-investigational information held by the police (discipline records, for example ${ }^{59}$ ), to hold that investigational files held by the police are not to be disclosed under the Stinchcombe procedure is to allow the police to arbitrarily categorize their files in such a way as to frustrate full answer and defence. Again the bankruptcy investigational file, the extreme relevance of which cannot be doubted in the Stinchcombe prosecution, shows that such a distinction needs to be soundly rejected. ${ }^{60}$

As discussed by Wayne Renke, the whole issue of "possession," has the potential to seriously erode the faimess sought by Sopinka J. in Stinchcombe. ${ }^{61}$ It is significant that every time a piece of information is held not to be in the possession of the Crown (particularly police records, but which may also relate to other government departments), all responsibility of the Crown in relation thereto is removed. To suggest that the defence has the same ability as the Crown to access such information is to deny reality, as the third parties simply will not discuss these matters with a criminal defence lawyer. Further, the Crown will often obtain valuable information by searching in other places (and usually by just asking questions without the necessity of a court

and in providing ongoing disclosure. Failure to comply with this initial and continuing obligation to disclose relevant and non-privileged evidence may result in a stay of proceedings or other redress against the Crown, and may constitute a serious breach of ethical standards. With respect to the latter, of necessity, great reliance must be placed on the integrity of the police and prosecution bar to act in the utmost good faith. It is for this reason that departures from this onerous obligation are treated as very serious breaches of professional ethics.

See the discussion infra note 63 and accompanying text.

See Campbell, supra note 33; $R$. v. Trang, [2002] 6 W.W.R. 524 (Alta. Q.B.); and $R$. v. Chan, [2002] 7 W.W.R. 223 (Alta. C.A.). See also the very detailed summary of the arguments and the analysis by Sulyma J. in $R$. v. Chan, [2002] A.J. No. 1019, online: QL (AJ).

See, e.g., $R$. v. Szczerba, [2002] A.J. No. 915, online: QL (AJ).

$R$. v. $O^{\prime}$ Connor, [1995] 4 S.C.R. 411 [hereinafter $O^{\prime}$ Connor].

See the article by Wayne Renke in this issue at 593.

See the article by John K. Phillips in this issue at 539 .

Supra note 59. 
application) and thereby find information which may prove essential in the conviction of an accused. For the same reason, the defence is positively disinclined to go on blind searches of third-party records lest the Crown's case is thereby strengthened. All of this means that relevant evidence which may be crucial to the discovery of truth will not be discovered, let alone presented to the court. A "minister of justice," above all, is interested in truth. The Court of Appeal's concern in Siemens, of Crown counsel being overworked, rings hollow. If there are not enough Crown prosecutors to do the job mandated by principles of justice then sufficient numbers should be hired to remedy that situation.

\section{THE Fraying Of THE SILVER THREAD: DEDICATION, WORKLOAD AND EXPERIENCE}

Certainly some practices by some Crown offices suggest individual offices do not take seriously the silver thread as set out by the Supreme Court. Justice Canada, for example, and in spite of its own guidelines ${ }^{62}$ suggesting this should not be done (absent exceptional circumstances), has assigned prosecutors from their Integrated Proceeds of Crime investigative units (IPOC) to the eventual prosecution resulting therefrom and indeed assigned those same prosecutors to roles in disclosure decisions in the resulting prosecution. ${ }^{63}$ In Regan, the Supreme Court considered the principles relating to the division of responsibilities between the Crown and the police. The majority reasons provided by Le Bel J. fail to make clear that the role of case prosecutors should be kept distinct and independent from that of the investigative team. Justice Le Bel did say,

The need for a separation between police and Crown functions has been reiterated in reports inquiring into miscarriages of justice which have sent innocent men to jail in Canada. The Royal Commission on the Donald Marshall, Jr., Prosecution, Findings and Recommendations (1989) ("the Marshall Report") speaks of the Crown's duty this way: "In addition to being accountable to the Attorney General for the performance of their duties, Crown prosecutors are accountable to the courts and the public. In that sense, the Crown prosecutor occupies what has sometimes been characterized as a quasijudicial office, a unique position in our Anglo-Canadian legal tradition" (pp. 227-28) The Marshall Report emphasizes that this role must remain distinct from (while still cooperative with) that of the police (at p. 232):

The Federal Prosecution Deskbook, Minister of Justice, 2000, ISBN 0-662-29437-8. Cat. no. J2172/2000E, JUS-775E, where at part 11.4 the Deskbook states, inter alia, as follows:

As a result, these units [IPOC] represent a significant change in the Attorney General's role in the administration of justice, since Crown counsel are clearly identified as part of the investigative team. These units are also a good illustration of the effectiveness of a multidisciplinary approach. To ensure that objectivity and independence is maintained. the ultimate decision to prosecute a given case is taken by the Prosecution Group Head or the Regional Director. Absent exceptional circumstances, the actual prosecution is carried out by counsel in the Regional office, and not by counsel from the unit [emphasis added]. 
We recognize that cooperative and effective consultation between the police and the Crown is also essential to the proper administration of justice. But under our system, the policing function - that of investigation and law enforcement - is distinct from the prosecuting function. We believe the maintenance of a distinct line between these two functions is essential to the proper administration of justice. ${ }^{64}$

It is argued that the complexity of many modern prosecutions, particularly drug and serious economic crime cases, require the police to maintain close contact with Crown counsel during the investigative stage, as investigative techniques formerly thought to have been legal have been frequently found to be unconstitutional by the courts. The argument continues that law enforcement is a continuum and the roles of the police in investigating and the Crown in prosecuting are interdependent. Thus while both have separate responsibilities, they must inevitably work in partnership to enforce criminal laws effectively. While everyone is in agreement that the police are often in need of legal advice and should be encouraged to seek it, it is the eventual assignment of those IPOC lawyers to the resulting prosecution with a role in disclosure decisions which fails to maintain the necessary division between the investigators and the prosecutors. $^{65}$

As recently stated in Dix v. Canada (A.G.),

In Canada there is a functional, legal, and ethical division between the police and prosecutors. The police conduct the investigation. Prosecutors conduct the in-court prosecution. There is a good reason for that division, as it assists in ensuring objectivity and fairness. If a prosecutor is intrinsically involved in the investigation, there is a greater risk that he or she will lose objectivity when it comes time to assess the legal strength of the case and hence making a determination about whether there is reasonable and probable cause to lay charges and to have the police proceed. ${ }^{66}$

This is also true relating to disclosure decisions. A prosecutor who is too close to an investigation may have a stake in the conviction of the targets of that investigation. This is clearly inconsistent with that prosecutor's role which, according to Boucher, "excludes any notion of winning or losing." 67 Further, a prosecutor with a stake in winning a case brought forward by the police cannot remain objective, especially when the Supreme Court's own judgment in Campbell suggests the police are the clients of Crown counsel when they receive advice on the lawfulness of proposed police steps in an investigation. ${ }^{68}$ Their discussions are therefore entitled to the protection of solicitor-client privilege and thus not disclosable absent an applicable exception. This must be inconsistent with the Crown's silver thread role in our administration of justice, as set out in the above judgments. 
Further, in these days of public clamour concerning the perceived failings of the justice system, the Crown and the police are pulled in many directions. Legal educators have noted a significant increase in students entering law school with the intention of righting the wrongs of the justice system. Many of these students will go on to be prosecutors with the intention of ensuring that the system gives offenders their "just desserts." Most will eventually be talented and dedicated prosecutors but will be in serious need of guidance in fulfilling the role the system expects of them. Provincial governments have generally failed to support their Crown's offices and not accorded their staff with the respect needed for the difficult job they undertake. In Alberta, for example, it is clear to even the casual observer that the government by and large does not respect lawyers, including its own prosecutors. Workloads, as well as a whole range of employment practices, have led to large defections from the Crown Prosecutor's Offices resulting in prosecutors who are inexperienced and severely overworked. ${ }^{69}$ While I have an immense respect for many dedicated Crown Prosecutors with whom I have dealt over the past two decades, many of them have moved from the employ of the Crown. It is clear that the government's failure to support its own legal department has placed a severe strain on Crown offices, making it difficult for their prosecutors to fulfill the role given them by the Court.

It is difficult for the employer to measure the value of an individual prosecutor when his role is defined in such a dichotomous manner. Crown prosecutors who fulfill the role assigned will not "get their man" as often as their conviction-oriented boss may wish. ${ }^{70}$ Indeed, some prosecutors seem to succeed in spite of a general opinion of many members of the bar that those same prosecutors do not even attempt to fulfill the role the courts have set out for them." These individuals are thankfully a small

Canada, Criminal Prosecutions: Personnel and Expenditures 2000/0I (Ottawa: Canadian Centre for Justice Statistics (Statistics Canada), 2002). This report finds that in 2000-2001 Alberta (5.5) had the lowest number of criminal prosecutor's per 100,000 population while British Columbia had the highest (8.6). Further, with 165 prosecutors handling 79,060 cases, the caseload per prosecutor was an astounding 479 cases handled in the 2000-2001 fiscal year. This too was the highest of all Canadian jurisdictions. Recently, the Attorney General has shown an increased willingness to listen to the complaints of Crown Prosecutors resulting in several improvements in salaries and benefits. It is doubtful these are of a sufficient magnitude to result in a significant change in the above figures. It is difficult to gauge, but constant complaints have also been heard about the hampering of individual prosecutor's discretionary decisions. It is clearly important that the government commit to ensuring that prosecutors are properly supported and trained. Further "Crown Schools" are valuable and need to be continued.

I do not suggest that all Chief Crown Prosecutors are conviction-oriented. but at least some have been so.

" See Dix, supra note 66. This astounding case might suggest a rogue Crown prosecutor, although one needs to note the ongoing relationship between the prosecutor and the RCMP, as noted by Ritter J., as he then was, at para. 294:

Overall, I am satisfied that Arnold Piragoff's involvement in the investigation stepped over the legal, functional, and ethical division which should exist between the respective functions of the police and prosecutors and that his involvement was greater than it needed to be and greater than it was desirable to be. This raises concerns about his ultimate objectivity in the conduct of, and decision to continue. the prosecution, including his ability to assess the critical issue of reasonable and probable cause.

It is extremely ironic that, in reading this civil judgment, it is clear that Dix was able to access significantly more information by civil disclosure rules than would ever be obtained in a criminal 
minority, but what remains is a very large group of mostly junior lawyers struggling to keep their heads above water. It is the person's quality that is more important than that person's ability to win trials. One wonders if it was the failure to understand this point that led to the Stinchcombe decision in the first place, and whether such failure continues to haunt the halls of Alberta Justice and other provincial justice departments.

\title{
VIII. STRENGTHENing THE Silver ThREAD: A Hatchet Not a SCALPEL
}

The law of remedies has been ineffective in ensuring that the Crown follows its disclosure duty. First, it is necessary to point out that while Stinchcombe purported to base the right to full disclosure on common law and statutory principles, the Supreme Court has gone on to place the right to disclosure under s. 7 of the Charter. In $R$. v. Carosella:

\begin{abstract}
The right to disclosure of material which meets the Stinchcombe threshold is one of the components of the right to make full answer and defence which in turn is a principle of fundamental justice embraced by s. 7 of the Charter. Breach of that obligation is a breach of the accused's constitutional rights without the requirement of an additional showing of prejudice. To paraphrase Lamer C.J. in Tran, the breach of this principle of fundamental justice is in itself prejudicial. The requirement to show additional prejudice or actual prejudice relates to the remedy to be fashioned pursuant to s. 24(1) of the Charter. ${ }^{72}$
\end{abstract}

Second, the members of the Supreme Court seem to disagree on the effect of a failure to disclose. In the above passage it seems that the obligation to disclose represents a breach of the accused's s. 7 right and therefore is contrary to the principles of fundamental justice. On the other hand, in a complicated breakdown in judgments in $R$. v. $O^{\prime}$ Connor, L'Heureux-Dubé J., speaking for four members of the nine person court, which for some purposes, when coupled with the short judgment of Cory J. with whom Iacobucci J. agreed, represented the majority of the Court, said,

Non-disclosure by the Crown normally falls within the second category described above. Consequently, a challenge based on non-disclosure will generally require a showing of actual prejudice to the accused's ability to make full answer and defence. In this connection. I am in full agreement with the Court of Appeal that there is no autonomous "right" to disclosure in the Charter.

...the right of an accused to full disclosure by the Crown is an adjunct of the right to make full answer and defence. It is not itself a constitutionally protected right. What this means is that while the Crown has an obligation to disclose, and the accused has a right to all that which the Crown is obligated to disclose, a simple breach of the accused's right to such disclosure does not. in and of itself, constitute a violation of the Charter such as to entitle a remedy under s. 24(1). This flows from the fact that the non-disclosure of information which ought to have been disclosed because it was relevant, in the sense there was a reasonable possibility it could assist

72 R. v. Carosella, [1997] I S.C.R. 80 at para. 37, online: QL (SCC) [hereinafter Carosella], citing the Court's previous judgment in $R$. v. Tran, [1994] 2 S.C.R. 951. 
the accused in making full answer and defence, will not amount to a violation of the accused's s. 7 right not to be deprived of liberty except in accordance with the principles of fundamental justice unless the accused establishes that the non-disclosure has probably prejudiced or had an adverse effect on his or her ability to make full answer and defence.

It is the distinction between the "reasonable possibility" of impairment of the right to make full answer and defence and the "probable" impairment of that right which marks the difference between a mere breach of the right to relevant disclosure on the one hand and a constitutionally material non-disclosure on the other.

Where the accused seeks to establish that the non-disclosure by the Crown violates 5.7 of the Charter, he or she must establish that the impugned non-disclosure has, on the balance of probabilities, prejudiced or had an adverse effect on his or her ability to make full answer and defence. It goes without saying that such a determination requires reasonable inquiry into the materiality of the nondisclosed information. Where the information is found to be immaterial to the accused's ability to make full answer and defence, there cannot possibly be a violation of the Charter in this respect. I would note, moreover, that inferences or conclusions about the propriety of the Crown's conduct or intention are not necessarily relevant to whether or not the accused's right to a fair trial is infringed. The focus must be primarily on the effect of the impugned actions on the faimess of the accused's trial. Once a violation is made out, a just and appropriate remedy must be found. ${ }^{73}$

Clearly, the members of the Supreme Court do not agree whether a breach of the right to disclosure is (1) an independent right entitled to remedial action; or (2) a component of the right under s. 7 entitled to a remedy only if prejudice to fair trial rights have occurred and are proven by the defence. This is more than semantics, but essential to the issue of remedies. In L'Heureux-Dubé J.'s view, I suggest, the Crown could approach disclosure not from the basic Stinchcombe test of possible relevance, but rather from the perspective of whether non-disclosure would cause prejudice to the accused. In other words, if remedies only occur where the accused is prejudiced, why disclose if no prejudice is foreseen?

The issue was more fully discussed in a series of cases decided by the Supreme Court in $1998 .^{74}$ In Dixon, a unanimous Supreme Court, in an obvious compromise amongst members of the Court, held both that

where an accused demonstrates a reasonable possibility that the undisclosed information could have been used in meeting the case for the Crown, advancing a defence or otherwise making a decision which could have affected the conduct of the defence, he has also established the impairment of his Charter right to disclosure; ${ }^{75}$ fully discussed by my colleagues Koshan and Renke in their articles in this issue at 655 and 593 respectively. 
and that

The right to full disclosure is just one component of the right to make full answer and defence. It does not automatically follow that solely because the right to disclosure was violated, the Charter right to make full answer and defence was impaired. ${ }^{76}$

The Supreme Court was considering when a new trial should be ordered on appeal as a result of a failure to make full disclosure at or before the previous trial. The twostep analysis set out by the Supreme Court in this series of decisions was later summarized by Rosenberg J.A. of the Ontario Court of Appeal in R. v. Babinski, as follows:

1. The appellant must demonstrate a violation of his right to disclosure by showing that there is a reasonable possibility that the undisclosed information could have been used in meeting the case for the Crown, advancing a defence or otherwise making a decision that could have affected the conduct of the defence.

2. The appellant must demonstrate on a balance of probabilities that the right to make full answer and defence was impaired as a result of the failure to disclose by showing that there is a reasonable possibility the non-disclosure affected the outcome at trial or the overall fairness of the trial process. This involves a two step analysis in the appellate court:

i. If the appellate court is persuaded that there is a reasonable possibility that, on its face, the undisclosed information affects the reliability of the conviction a new trial should be ordered. ii. Even if the evidence on its face does not affect the reliability of the conviction, the appellate court must consider the overall faimess of the trial process. This will require the court to assess, on the basis of a reasonable possibility, the lines of inquiry with witnesses or the opportunities to gather additional evidence that could have been available to the defence had the information been disclosed. In considering the overall fairness of the trial process. the court will take into account defence counsel's diligence in pursuing disclosure from the Crown. A lack of due diligence is a significant factor in determining whether the non-disclosure affected the fairness of the trial process. ${ }^{77}$

Justice Cory, for the Court in the leading case of Dixon, went further than dealing simply with the issue of remedies on appeal. He made it clear that the onus on the defence at trial is lower than it is on appeal. At trial, if the Court is persuaded that undisclosed information meets the Stinchcombe threshold, an accused has met his burden to establish a "violation of his Charter right to disclosure." 78 At trial the appropriate remedy, he says, apparently in passing, is an order for production or an adjournment.

Both of these rulings are disappointing and ineffective. The trial remedy analysis is more complicated than the approach suggested above. While it does appear that at trial, after Dixon, nothing further need be established than a lack of disclosure on the Stinchcombe standard, the issue of what remedy should flow therefrom is more 
complicated than just an order for production and an adjournment. I do not intend to fully discuss the jurisprudence on s. 24 , or how s. 24 has been applied in lack of disclosure cases. Previous case law, though, has made clear that there are a whole range of orders that can and are made in such cases, from a complete stay of the proceedings to a simple order for production, often coupled with an adjournment. In $O^{\prime}$ Connor L'Heureux-Dubé J. said, in an oft-quoted passage,

Remedies less drastic than a stay of proceedings are of course available under s. 24(1) in situations where the "clearest of cases" threshold is not met but where it is proved, on a balance of probabilities, that $\mathrm{s} .7$ has been violated. In this respect the Charter regime is more flexible than the common law doctrine of abuse of process. However, this is not a reason to retain a separate common law regime. It is important to recognize that the Charter has now put into judges' hands a scalpel instead of an axe - a tool that may fashion, more carefully than ever, solutions taking into account the sometimes complementary and sometimes opposing concerns of fairness to the individual, societal interests, and the integrity of the judicial system. ${ }^{79}$

The reference to the "clearest of cases" is, of course, a reference to the appropriate test for a stay of proceedings which is available in a breach of right to disclosure case but only rarely so.

What is disappointing is the continued view of the Supreme Court that remedies for lack of disclosure at trial should simply focus on the provision of the missing disclosure to the defence. When one connects Dixon, Chaplin, and Stinchcombe, one is left with the inexorable impression that the Crown faces little risk for failing to make full disclosure. The view that the Crown will make full disclosure upon initial demand by the accused seems to rest solely on the ethical obligation of Crown counsel. If the Crown fails to provide disclosure the defence will apply for an order to produce it. Without any further consequence in the proceedings, the only compelling force upon the Crown is the possible use of a Law Society proceeding ${ }^{80}$ or potentially a civil suit for malicious prosecution. ${ }^{81}$ Both of these remedies are largely impractical for the

$O$ 'Connor, supra note 58 at para. 69 [emphasis added].

Soe Krieger v. Law Society of Alberta, [2002] S.C.J. No. 45, online: QL (SCJ). The judgment, which was released after the writing of this article, is very significant. The unanimous decision suggests disclosure decisions are not "discretionary" decisions of the Crown (and therefore immune from review by the trial judge), as the Crown has a duty to ensure full disclosure is made. The Court holds, at para. 54 .

In Stinchcombe, supra, the Court held that the Crown has an obligation to disclose all relevant information to the defence. While the Crown Attorney retains the discretion not to disclose irrelevant information, disclosure of relevant evidence is not, therefore, a matter of prosecutorial discretion but, rather, is a prosecutorial duty. Absent an explanation demonstrating that the Crown Attorney did not act dishonestly or in bad faith, it is settled law, per Sopinka J. for the Court in Stinchcombe, supra, at p. 339, that "[t]ransgressions with respect to this duty constitute a very serious breach of legal ethics."

Krieger, an Edmonton prosecutor, had applied for and obtained from the Court of Appeal certiorari and prohibition ousting the Law Society's jurisdiction to determine whether the decision to delay disclosing a DNA test, which exonerated an accused, was done in bad faith and thus sanctionable by the Law Society. 
great majority of accused persons and do nothing to ensure that the ongoing criminal proceeding runs fairly. ${ }^{82}$ They do absolutely nothing to encourage the police to assist the Crown in carrying out its disclosure obligation.

This is also true of the Supreme Court's requirement that, upon appellate review, the due diligence of defence counsel is a "significant factor in determining whether the Crown's non-disclosure affected the fairness of the trial process." ${ }^{83}$ Placing the onus on defence counsel essentially places the duty on the defence to ensure fair trials rather than on the "minister of justice" prosecutor. There needs to be more in the law of disclosure to encourage Crown prosecutors to follow Stinchcombe's dictates. Certainly it is welcome that the Ontario Court of Appeal in Babinski interpreted Dixon to hold that the due diligence of defence counsel is not relevant to the first step of the analysis set out above. That is, if the appellate court is persuaded that there is a reasonable possibility that, on its face, the undisclosed information affects the reliability of the conviction, a new trial should be ordered. The lack of due diligence of the defence is irrelevant and the appeal should be allowed without more. In the absence, however, of the defence being able to make such a showing, the due diligence of the defence will be a significant factor in determining whether to allow the appeal, in spite of the fact that there has been a lack of disclosure that could have been used to meet the case of the Crown, advancing a defence or otherwise making a decision that could have affected the conduct of the defence.

What is very odd about these recent decisions is that most of the cases involve the non-disclosure of information held by the police, that was not turned over by the police, and which the courts say was "inadvertently" not disclosed. In Babinski, for example, a police interview of a jailhouse informant conducted

(1) before the informant made his allegation of a confession by the accused; but

(2) after the time he alleged the accused made the incriminating statement; and

(3) in which he specifically denied the accused had ever made an admission to him;

was assumed to be an "inadvertent" non-disclosure. ${ }^{84}$ This assumption is astounding, especially when one realizes the case had been tried twice and had gone all the way to the Supreme Court in the interim before the Crown "discovered" the non-disclosure. Further, the Crown had assured defence counsel that not only had full disclosure been made but that the interview in question did not relate to the case before the Court. I am not suggesting that the Crown in Babinski knew of the content of the interview and intentionally misled the defence, but quite obviously the Crown did not review it itself. It simply took the police assurances at face value. This is simply not inadvertence, certainly not on the part of the police. Whichever officer made the assurance to the 206 D.L.R. (4th) 444.

\$. Dixon, supra note 31 at para. 37.

*4 Babinski, supra note 77. 
Crown was, at least, wilfully blind to the content of the statement. Why would the Court not come to that conclusion on the evidence led there?

\section{CONClusion}

It is difficult to see how the defence's diligence is relevant where there is a complete lack of due diligence on the part of the prosecution in relation to making disclosure in the first place. It is the Crown who carries the duty to ensure full disclosure. The Crown must to be required to show that it exercised due diligence in making disclosure decisions, and failing such a showing significant defence remedies should flow. If this is not the case we are not only perpetuating sloppy Crown practice but in fact positively encouraging non-disclosure of relevant information and thus encouraging wrongful convictions and unfair trials. The Crown in Babinski chose to rely on the police; should it not therefore be responsible for the content of that advice? To suggest that this is inadvertent is to say that they have no duty to ensure full disclosure is made. Alas, this failing on the part of the police, which is the Crown's responsibility, plays no role in the Court of Appeal's decision to order a new trial. Where in this analysis is the encouragement of the Crown to act any differently on the next occasion?

Further, as Sopinka J. makes clear in Stinchcombe, the force driving his decision to require full disclosure was the wish to encourage early resolution of cases before they arrived at the courts. Why then are the courts not encouraging early full disclosure? The focus on defence counsel and its need to enforce disclosure totally denies the desirability that disclosure occur early in the proceeding. The total focus of the later Supreme Court cases has been on the fairness of the "trial" process to the exclusion of all pretrial discussions.

In $O^{\prime}$ Connor, L'Heureux-Dubé J. said,

the Charter has now put into judges' hands a scalpel instead of an axe - a tool that may fashion, more carefully than ever, solutions taking into account the sometimes complementary and sometimes opposing concerns of faimess to the individual, societal interests, and the integrity of the judicial system. $^{85}$

The integrity of the judicial system led the Supreme Court to require full disclosure in Stinchcombe. There the Court held that society's interests require full disclosure. If a scalpel allows the Court to carefully provide a solution to the problem without the overkill of a blunt instrument - like an axe - one can hardly disagree. On the other hand, if a scalpel means that one simply orders disclosure and adjourns the matter, then it is doing nothing to fix the problem and nothing to satisfy the accused's interests, society's interests, nor anything to protect the integrity of the judicial system. While it may be said that an axe is going too far, as the Supreme Court has shown itself divided on the use of stays of proceedings, perhaps a hatchet, with a blunt end, but which can be swung with considerably more accuracy than an axe, is needed to finally achieve the promise in Stinchcombe of a just system that believes in early and full disclosure. 